\title{
Analysis of the concept of nursing educational technology applied to the patient
}

\author{
Análise do conceito de tecnologia educacional em enfermagem aplicada ao paciente \\ Análisis del concepto de tecnología educacional en enfermería aplicada al paciente
}

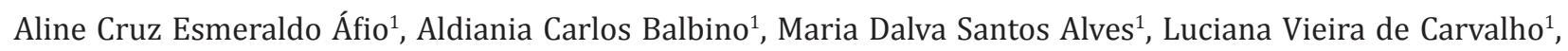
Míria Conceição Lavinas Santos ${ }^{1}$, Natália Rodrigues Oliveira ${ }^{1}$

It is aimed at analyzing the concept of educational technology, produced by nursing, applied to the patient. Rodgers' Evolutionary Method of Concept Analysis was used, identifying background, attributes and consequential damages. 13 articles were selected for analysis in which the background was identified: knowledge deficiency, shortage of nursing professionals' time, to optimize nursing work, the need to achieve the goals of the patients. Attributes: tool, strategy, innovative approach, pedagogical approach, mediator of knowledge, creative way to encourage the acquisition of skills, health production instrument. Consequences: to improve the quality of life, encouraging healthy behavior, empowerment, reflection and link. It emphasizes the importance of educational technologies for the care in nursing, to boost health education activities.

Descriptors: Concept Formation; Educational Technology; Nursing.

Objetivou-se analisar o conceito de tecnologia educacional, produzido pela Enfermagem, aplicada ao paciente. Utilizou-se Modelo Evolucionário de Análise de Conceito, identificando-se antecedentes, atributos e consequentes. Selecionaram-se 13 artigos para análise nos quais se identificaram os antecedentes: deficiência de conhecimento, escassez de tempo dos profissionais, otimizar trabalho da enfermagem, atingir as metas dos pacientes; atributos: ferramenta, estratégia, abordagem inovadora, abordagem pedagógica, mediadora de conhecimentos, forma criativa de estimular a aquisição de competências, instrumento de produção da saúde; consequentes: melhora da qualidade de vida, estímulo a comportamentos saudáveis, empoderamento, reflexão e vínculo. Enfatiza-se a importância das tecnologias educacionais para o cuidado em Enfermagem, ao dinamizar as atividades de Educação em Saúde.

Descritores: Formação de Conceito; Tecnologia Educacional; Enfermagem.

El objetivo fue analizar el concepto de tecnología educacional, producido por la Enfermería, aplicada al paciente. Se utilizó el Modelo de Evolución de Análisis del Concepto, identificándose antecedentes, atributos, y consecuentes. Se seleccionaron 13 artículos para análisis, donde se identificaron los antecedentes: deficiencia de conocimiento, escasez de tiempo de los profesionales de enfermería, optimización del trabajo da enfermería, necesidad de alcanzar metas de pacientes; atributos: herramienta, estrategia, abordaje innovador, enfoque pedagógico, mediadora de conocimientos, forma creativa de estimular la adquisición de competencias, instrumento de producción de salud; consecuentes: mejora de calidad de vida, estímulo a comportamientos saludables, empoderamiento, reflexión y vínculo. Se enfatiza la importancia de las tecnologías educacionales para la atención de enfermería, al dinamizar actividades de educación en salud.

Descriptores: Formación de Concepto; Tecnología Educacional; Enfermería.

$\overline{{ }^{1} \text { Universidade Federal do }}$ Ceará. Fortaleza, CE, Brazil.

Corresponding author: Míria Conceição Lavinas Santos

Rua Alexandre Baraúna, 1115. Rodolfo Teófilo. CEP: 60430-160. Fortaleza, CE, Brazil. E-mail: mlavinas@fortalnet.com.br 


\section{Introduction}

Technologies are as old as the human species $^{(1)}$ and although there is an area of accelerated development in the theoretical, instrumental and operational aspects, it is not possible to loose from site certain fundamental concepts and principles, once they make the assimilation easier, and the better use by part of the subjects.

Nursing grew and developed together with the arrival of technology, whether it is hard, light-hard or light ${ }^{(2)}$. Along the years, an increase in the production of technology by Nursing was noticed (3), there has been reference to the educational technology (devices for the mediation of processes of teaching and learning, used among educators and learners, in the several processes of formal-academic, formalcontinuing education); assistential technology (devices of mediation for the processes of care, applied by professionals with the users-clients of the health system of primary, secondary and tertiary attention) and managerial technology (devices for the mediation of management processes, used by professionals of the services and units and of distinct health systems ${ }^{(4)}$.

Concerning educational technology, it is believed that they can be conceived in different ways if analyzed in the course of history and by several areas of knowledge. In the era of technological society, understanding the amplitude and implication of educational meaning linked to educational technology in nursing, makes the fundament of studies which that will be developed in the area easy.

The nurse, when exercising the role of educator, must develop educational strategies which make the significant learning easy ${ }^{(5)}$. For that, he needs to know and use coherent concepts able to improve the care in health.

When taking care of a patient in order to promote 'empowerment', the nurse has several tool of communication. So, when analyzing a study about educational technology in health ${ }^{(3)}$, the increase in the production of a variety of educational material was observed, such as educational tool, devices applied in several scenarios and with innumerous purposes.

Facing the magnitude of the context, the following questions emerged: Which concept of educational technology turned to the patient is being used in the productions in the area of nursing? Which characteristics (attributes) are pointed by them?

Innumerous sets of words can express only one concept. The analysis of the concept allows the clarification of vague and ambiguous understanding ${ }^{(6-7)}$, through the elimination of the use of the preconceived idea of the concept, and orientation starts being mediated by the literature. The act of clarifying a concept does not mean a final point, but a critical step in the development of the knowledge related of the concepts of interest in nursing, considering it dynamic and dependent on the context in which it is inserted ${ }^{(8)}$. The elucidation of a concept is considered an important step in the development of the knowledge in the Science of Nursing ${ }^{(9)}$.

The study is aimed at analyzing the concept of educational technology produced by nursing, applied to the patient.

\section{Method}

The study adopted as theoreticalmethodological referential Rodgers' Evolutionary Method of Concept Analysis. In this method, the analysis of the evolution of a concept occurs in an inductive and strict way. It identifies its importance, relevance and meaning and it is seen as dynamic, ample, absolute and clear ${ }^{(6)}$.

According to Rodgers' Evolutionary Method of Concept Analysis, six steps are proposed as follows: 1. Identify the concept and the associate expressions; 2. Select an appropriate domain for the collection; 3. Collect the data to identify the attributes and the contextual basis to the concept; 4 . Analyze the data related to the characteristic of the concept; 5 . Identify 
an exemplar of the concept, if appropriate; 6. Identify the hypothesis and the implications for the later development. It is valid to outstand the fact that, some of these steps are performed in a concomitant way during the study, once they are complementary, but independent ${ }^{(6)}$. In the present study, however, the last two steps were not performed.

The concept analyzed was the Nursing Educational Technology applied to the patient. Considering that the nursing professionals are the main subjects responsible for the process of education in health, and that the educational technologies are important strategies for the execution of these activities, the analysis became relevant for the practice of these professionals. The analysis was restrained to the patients, once the educational technologies applied to these people have different modalities of teaching and of transference of knowledge.

The domains used for the collection of the information referring to this concept were: Base de Dados de Enfermagem (BDENF), Literatura LatinoAmericana e do Caribe em Ciência da Saúde (LILACS), Scopus and Cumulative Index of Nursing and Allied Health Literature (CINAHL), once they are considered relevant for the domains of nursing. It is highlighted that the period of publishing of the article was not established, with the objective to obtain the largest number of publishings on the theme.

The data were collected in June 2013, using the following descriptors: educational technology, Nursing and Health Education, with the use of a tool to register the databases, title, year of publishing, concept used, attributes, background and consequences.

The criteria for inclusion of the articles were: comprise the guiding question and be integrally available in Portuguese, English or Spanish. After the reading of the title and briefing, the ones who had education technology created and applied by nurses to the patients were selected for reading. The following issues were excluded: the editorials and letter to the editors, integrative reviews, reflexive articles, studies which applied educational technology to other people or mentioned the expression educational technology, but it was not applicable to the patient.

After the exhausting reading of the selected articles and collection of the necessary information, the data were exposed in tables and figures, discussed in a descriptive way and analyzed according to the pertinent literature.

\section{Results}

After the pre-selection of 700 articles, 23 publications were chosen. Ten articles were excluded, five by the repetition in other databases and five, after the integral reading of the text, did not comply with the proposal of the study.

Table 1 - Selection of articles according to the databases and the processes of selection

\begin{tabular}{lccccc}
\hline Basis & $\begin{array}{c}\text { Initial } \\
\text { selection }\end{array}$ & $\begin{array}{c}\text { Selection } \\
\text { after the } \\
\text { reading of } \\
\text { the title and } \\
\text { briefing }\end{array}$ & $\begin{array}{c}\text { Exclusion } \\
\text { after the } \\
\text { reading of } \\
\text { the complete } \\
\text { text }\end{array}$ & Repeated Total \\
\hline LILACS & 14 & 6 & - & 4 & 2 \\
BDENF & 08 & 4 & 1 & - & 3 \\
SCOPUS & 641 & 12 & 4 & 1 & 7 \\
CINAHL & 37 & 1 & - & 5 & 1 \\
Total & 700 & 23 & 5 & 5 & 13 \\
\hline
\end{tabular}

The scientific production chosen was published from 2003 to 2012 (Figure 1). There was a predominance of articles in the English language, with seven publishings at Scopus, and the majority was published in the last five years. It is observed that 2012 was the year with the highest number of publications on educational technology, produced by nursing and applied to the patient.

Besides that, the fact that the theme was published for nine years subsequently was highlighted, even if one article a year (Figure 1). 


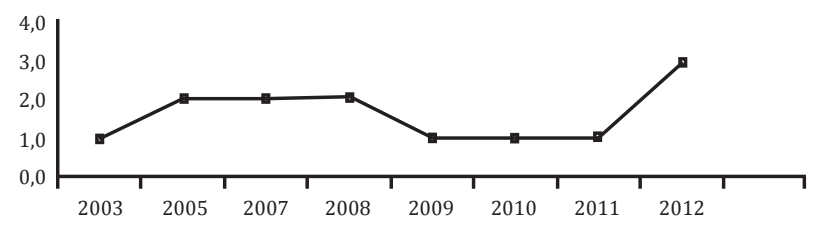

Figure 1 - Distribution of the scientific articles, according to the year of publishing

The types of educational technologies found were interview ${ }^{(10)}$, simulation and video $^{(11)}$, counseling $^{(12)}$, slides $^{(13)}$, manual, booklets, educational game e website $^{(3)}$, primer ${ }^{(3,14-16)}$, softwares ${ }^{(17-19)}$ and active methodologies (theater, collage) ${ }^{(20)}$.

After the analysis of the article, the attributes, background and consequences which represent the concept under study were highlighted as shown in figure 2. They represent the assimilation of the concept by the nursing professionals in several scenarios of acting, in the care turned to the education of the patient.

\begin{tabular}{|c|c|c|}
\hline Background & Attributes & Consequences \\
\hline $\begin{array}{l}\text { - Deficiency of } \\
\text { knowledge; } \\
\text { - Difficulty of } \\
\text { memorization; } \\
\text { - Vulnerability; } \\
\text { - Shortage of time of } \\
\text { the professionals; } \\
\text { - Optimize the work } \\
\text { of nursing; } \\
\text { - To reach the } \\
\text { targets of } \\
\text { assistance to the } \\
\text { patients; } \\
\text { - Doubts on the } \\
\text { condition of health; } \\
\text { - Resistance to the } \\
\text { orientations; } \\
\text { - Knowledge on the } \\
\text { feelings and needs; }\end{array}$ & $\begin{array}{l}\text { - Tool; } \\
\text { - Strategy; } \\
\text { - Innovative } \\
\text { approach; } \\
\text { - Resource; } \\
\text { - Support; } \\
\text { - Processes; } \\
\text { - Artifact; } \\
\text { - Acquisition of } \\
\text { competences; } \\
\text { - Mediator of } \\
\text { knowledge; } \\
\text { - Health promotion; } \\
\text { - Educational } \\
\text { process in health; } \\
\text { - Useful for care; } \\
\text { - Interaction; } \\
\text { - Pedagogical } \\
\text { approach; }\end{array}$ & $\begin{array}{l}\text { - Improvement of the } \\
\text { quality of life; } \\
\text { - Development of } \\
\text { competences; } \\
\text { - Reduction of costs; } \\
\text { - Satisfaction with } \\
\text { the nursing care; } \\
\text { - Healthy behavior; } \\
\text { - Stimulates } \\
\text { reflection; } \\
\text { - Favors the link; } \\
\text { - Creative capacity of } \\
\text { the group; } \\
\text { - Qualified } \\
\text { assistance; } \\
\text { - Makes the teaching- } \\
\text { learning process } \\
\text { easy; } \\
\text { - Promotes } \\
\text { acquisition of } \\
\text { knowledge and } \\
\text { abilities; } \\
\text { - Produces more } \\
\text { adhesion; } \\
\text { - Minimizes errors } \\
\text { and anxiety; } \\
\text { "Empowerment"; } \\
\text { - Uniformizes } \\
\text { information }\end{array}$ \\
\hline
\end{tabular}

Figure 2 - Exposition of the background, attributes and consequences of technology

\section{Discussion}

Educational technologies are facilitating instruments of the teaching-learning process used as a means of transference of knowledge, providing the subject with the participation in a moment of exchange of experiences leading to the improvement of abilities ${ }^{(14)}$.

The technologies presented in the study were applied in several scenarios among them hospital, schools, community and home. So, it is observed that these are excellent pedagogical means. Only one study, produced by the Brazilian researches, reports the experience of creation of several technologies for the education of patients, under the perspective of a pedagogy of problematization. This recovers previous knowledge of the subjects, requiring a reflection concerning reality in order to reach significant learning ${ }^{(21)}$.

All the studies aimed at transmitting the essential information to minimize doubts in order to change behaviors of risk or because it is an educational resource of easy access that complemented or clarified instructions provided by the professionals. The objective of the educational materials must be to facilitate the work of the health team in communication and orientation of patients and family members, in the search of the learning of the learners, in order to be considered educational. These materials subsidize the verbal orientation of the health professionals and dynamize the activities of Health Education.

It was observed that the studies had reported the fact that, in approximately one decade (2003 to 2012), nursing used several educational technologies to take care of the patient, of those, the booklets and softwares were the most used resources. The booklet is an educational material which makes a better comprehension to patient possible, concerning the health problem experienced, helping him to reflect on his style of life and to develop the capacity of autonomy in health care ${ }^{(22)}$. Sites, softwares and videos, are tools which enable the acquisition of knowledge in a non 
linear manner by the learners through interaction, simulations, images and sounds which show the reality of the everyday activities, stimulating reflection and favoring learning ${ }^{(3)}$.

The crescent technological evolution supported by the needs of the society expresses new possibilities of use of those materials in the practices of care and teaching of health. In order to understand a phenomenon or event and its complications in several scopes of life, it is important to know its background, which elucidates the process of conceptual formation, helping in the comprehension of the social context in which the term is inserted ${ }^{(6)}$. One of the more discussed backgrounds in the articles was the deficiency of knowledge of the patient, in the several themes covered by the articles.

Considering the frequent lack of knowledge of the learners on the conditions for the maintenance of health, leading to inadequate habits of life and, consequently, a greater vulnerability to disease, the adoption of educational strategies by the nurses makes feasible a greater knowledge of the learners concerning his health, aiming at the maintenance of health behavior ${ }^{(23)}$.

The doubts of the patient on the pathology which attacks him are frequently discussed in activities of Health Education. In an attempt to answer them, technologies are created as a creative and attractive way to disseminate information. Besides providing the reach of the targets of the patients, favoring the optimization of the work of nursing, which is background identified in the article.

When the elaboration of educational technology is proposed, the subjects to whom they are destined are assessed, once these peculiarities must be respected, in order to have continuous applications of those in the practice ${ }^{(1)}$. The background 'resistance to orientation' can be overcome once the correct selection of the modality in which information will be retransmitted is made, as seen in the articles of the sample. The nurses who implement educational technologies during the actions of health education must be committed to the social transformation of the person involved in the educational process in a coherent, continuous and sensitized way with the social and political developments of the people. Therefore, the formulation of technologies must integrate the doing, the doing and the being, mobilizing actions of human care.

The attributes were expresses as the words or expressions used by the author to define the concept under study ${ }^{(6)}$. According to those, it is noticed that the educational technology is seen as tool, resource and product. A study, whose objective is to analyze the concept of technology in nursing, showed the attributers 'product' and 'process' to the concept. Despite the fact that the concepts are not the same, there was an intrinsic relation among them ${ }^{(24)}$.

The technologies analyzed show the diversity of tools which the nurse uses to communicate with the patient. The communication can be face to face, as during the use of the booklets, manuals or counseling sessions or through computer resources as softwares and websites, having no need of the presence of the nurse during the use of these resources by the patient. The production of these materials makes possible their visualization as product, something concrete which the patient will be able the visualize according to his need. Integrating them to the teaching-learning process makes them potential mediators in the act of care.

The attribute promotion of health comes from the fact that the technologies are used to facilitate the taking of decision by the patient and/or the family, through the enhancing of the knowledge of the interest of the patient. Promoting more appropriate actions to promote a healthy life and the welfare, involves the care that 'empowers', that emerges as intentional activity, thus allowing the patient to acquire knowledge of himself and of that which surrounds him, it can exert changes in this environment and in his own behavior. Besides enabling him to define his own problems and needs, to understand how he can solve these problems with his own resources or with outside support ${ }^{(25)}$. 
The consequences are the situations, which the use of a concept can cause when observing its result in a practical situation ${ }^{(6)}$. In this study, there is reference to the events which use educational technologies.

The articles of the sample revealed as consequences: 'improvement in the quality of life', 'healthy behavior' and 'stimulus to reflection'. The use of educational materials contribute for the improvement of the level of knowledge, development of abilities and a greater autonomy of the person, being able to allow the subject to reflect on the behavior and actions which influence their standard of health ${ }^{(22)}$. So, they are considered effective didactic tools for the promotion of quality of life ${ }^{(26)}$.

Health education is linked to the promotion of the quality of life of the people and is established as institutional and communitarian tool to reach health. This expression is understood as a means to learn about health, however it includes the disposition of the learner to modify attitudes ${ }^{(27)}$. Educational activities which use educational technologies and aim at the change of behavior are inserted in the process of health education ${ }^{(28)}$.

Educational materials are devices used to mediate policies and practices of health. During an educational practice, if they are used adequately, they help in the transmission of information keeping in mind that, generally, they support the vertical communication between the professional and the patient just with the exposition with the information ${ }^{(29-30)}$. Educational technologies can be visualized as teaching material, however the opposite is not true, once a tool that has the purpose of teaching does not necessarily need to reach learning. The act of teaching has the objective to lead to learning but this target cannot be reached. But the educational technology has the purpose to educate and will only be considered educational if it has reached this objective.

Standardizing information was a consequence related to the concept under study. Although the information can be available in a printed or digitalized way, it does not limit the knowledge once the educational technologies must be the starting point so that the patients can continue the pursuit of knowledge. Besides that, they are liable to updating and adaptation to different cultures.

Despite the range of educational technologies produced by nursing, it was not possible to observe well defined historical landmarks in the studies which would guide the implemented technologies. It is known that, with the advancement of the computer science in health, there is a tendency for the choice of this means, using the computer logic with the patient. Traditional methods, however, are still used by nursing such as counseling, theater, collage and printed media, showing that the different technological nuances are important and they make part of the everyday experience of a nurse.

The reflection made possible by the analysis of the articles allows us to conclude that there was an evolution in the concept. The educator assumes an important role facing the news technologies presented, once he is worried about the content to be expressed, as it will be shown, and how that new learning can have a repercussion in the life of the subjects involved. The non obligation of the presence of the educator is according to the advancements occurred in the pedagogical area, it is up to new studies to permeate this perspective.

\section{Final Considerations}

The concept of educational technology has evolved along the years, it is not possible to associate a chronological evolution to the conception presented. The crescent technological evolution brings possibilities of use of new resources in the practices of care and teaching of health.

It is highlighted that the studies analyzed were published in the last ten years using several educational methods, relatively innovating (printed and computerized materials), characterizing boosting of the teaching-learning process.

The importance of the educational technologies for the nursing care is emphasized, once the teaching 
materials dynamize the activities of Health Educations, a peculiar action of nursing.

\section{Collaboration}

Alves MDS and Santos MCL contributed for the orientation and conception of work. Áfio ACE, Balbino AC, Carvalho LV and Oliveira NR contributed for the conception, analysis, interpretation of the data and writing of the article.

\section{References}

1. Kenski VM. Tecnologias e ensino presencial e a distância. Campinas: Papirus; 2008.

2. Barra DCC, Nascimento ERP, Martins JJ, Albuquerque GL, Erdmann AL. Evolução histórica e impacto da tecnologia na área da saúde e da enfermagem. Rev Eletr Enf. [periódico na Internet] 2006. [citado 2013 jul 29]; 8(3):422-30. Disponível em: http:// www.fen.ufg.br/revista/revista8_3/v8n3a13.htm

3. Fonseca LMM, Leite AM, Mello DF, Silva MAI, Lima RAG, Scochi CGS. Tecnologia educacional em saúde: contribuições para a enfermagem pediátrica e neonatal. Esc Anna Nery. 2011; 15(1):190-6.

4. Nietsche EA, Backes VMS, Colomé CLM, Ceratti RN, Ferraz F. Tecnologias educacionais, assistenciais e gerenciais: uma reflexão a partir da concepção dos docentes de enfermagem. Rev Latino-Am Enfermagem. 2005; 13(3):344-53.

5. Parker FM, Lazenby RB, Brown JL. Mission possible CD rom: instructional tool for preceptors. Nurse Educ Today. 2012; 32(5):561-4.

6. Rodgers BL, Knafl KA. Concept development in nursing - foundations, techniques, and applications. Philadelphia: WB Saunders; 2000.

7. Walker LO, Avant KC. Concept analysis. In: Walker LO, Avant KC. Strategies for theory construction in nursing. $4^{\text {th }}$ ed. New Jersey: Pearson Prentice Hall; 2005.

8. Fontenele FC, Pagliuca LMF, Cardoso MVLML. Cuidados com a pele do recém-nascido: análise de conceito. Esc Anna Nery. 2012; 16(3):480-5.

9. Tofthagen R, Fagerstrøm LM. Rodgers' evolutionary concept analysis - a valid method for de- veloping knowledge in nursing. Scad J Caring Sci. 2010; 24(Suppl 1):21-31.

10. Chambers M, Connor SL, Mcelhinney S. Substance use and young people: the potential of technology. J Mental Health Nurs. 2005; 1:179-86.

11. Browne JV, Talmi A. Family-based intervention to improve parent-child in the Neonatal Intensive Care Unit. J Pediatr Psychol. 2005; 30(8):667-77.

12. Johansson K, Salantera S, Katajisto J. Empowering orthopaedic patients through preadmission education: results from a clinical study. Patient Educ Couns. 2007; 66(1):84-91

13. Chen YC, Chiang LC. Effectiveness of education programs handwashing for families of children in pediatric intensive care units. J Clin Nurs. 2007; 16(6):1173-9.

14. Barros EJL, Santos SSC, Gomes GC, Erdmann AL. Educational geronto-technology for ostomized seniors from a complexity perspective. Rev Gaúcha Enferm. 2012; 33(2):95-101.

15. Nagel K, Wizowski L, Duckworth J, Cassano J, Hahn SA, Neal M. Using plain language skills to create an educational brochure about sperm banking for adolescent and young adult males with cancer. J Pediatr Oncol Nurs. 2008; 25(4):220-6.

16. Sousa CS, Turrini RNT. Creating e validatin educational material for patients undergoing ortognathic surgery. Asian Nurs Res. 2012; 6(4):166-72.

17. Lehmann ED. Usage of the www.2aida.org AIDA diabetes software website: a pilot study. Diabetes Technol Ther. 2003; 5(1):75-89.

18. O'Conner-Von S. Coping with Cancer: A Web-based Educational Program for Early and Middle Adolescents. J Pediatr Oncol Nurs. 2009; 26(4):230-41.

19. Brennan PF, Casper GR, Burker LJ, Johnson KA, Brown R, Valdez RS, et al. Technology enhanced practice for patients with chronic cardic disease home implementation and evaluation. Heart Lung. 2010; 39(6):34-46.

20. Maia ER, Lima Júnior JSP, Eloi AC, Gomes CC, Nobre MMF. Validação de metodologias ativas de ensino-aprendizagem na promoção da saúde alimentar infantil. Rev Nutr. 2012; 25(1):79-88.

21. Freire P. Educação como prática de liberdade. Rio de Janeiro: Paz e Terra; 2008. 
22. Torres HC, Candido NA, Alexandre LR, Pereira FL. 0 processo de elaboração de cartilhas para orientação do autocuidado no programa educativo em Diabetes. Rev Bras Enferm. 2009; 62(2):312-6.

23. Gubert FA, Santos ACL, Aragão KA, Pereira DCR, Vieira NFC, Pinheiro PNC. Tecnologias educativas no contexto escolar: estratégia de educação em saúde em escola pública de Fortaleza-CE. Rev Eletr Enf. [periódico na Internet] 2009 [citado 2013 jul 29]; 11(1):165-72. Disponível em: http:// www.fen.ufg.br/revista/v11/n1/v11n1a21.htm.

24. Aquino PS, Melo RP, Lopes MVO, Pinheiro AKB. Analysis of the concept of technology in nursing according to the evolutionary method. Acta Paul Enferm. 2010; 23(5):690-6.

25. Hammerschmidtk SA, Lenardt MH. Tecnologia educacional inovadora para o empoderamento junto a idosos com diabetes mellitus. Texto Contexto Enferm. 2010; 19(2):358-65.
26. Oliveira MS, Fernandes AFC, Sawada NO. Manual educativo para o autocuidado da mulher mastectomizada: um estudo de validação. Texto Contexto Enferm. 2008; 17(1):115-23.

27. Sousa LB, Torres CA, Pinheiro PNC, Pinheiro AKB. Práticas de educação em saúde no Brasil: a atuação da enfermagem. Rev Enferm UERJ. 2010; 18(1):55-60.

28. Cardoso MVLML. Tecnologia e enfermagem [editorial]. Rev Rene. 2009; 10(3).

29. Freitas FV, Rezende Filho LA. Modelos de comunicação e OSU de impressos na educação em saúde: uma pesquisa bibliográfica. Interface. 2011; 15(36):243-56.

30. Kelly-Santos A, Monteiro S, Rozemberg B. Significados e usos de materiais educativos sobre hanseníase segundo profissionais de saúde pública do Município do Rio de Janeiro, Brasil. Cad Saúde Pública. 2009; 25(4):857-67. 